\title{
Vindication of Chinese Traditional Legal Philosophy
}

\section{Lin ZHU}

Associate professor, doctor of laws,

Deputy director of Foreign Language \& Literature Research Institute, School of Foreign Language, CUPL, Director of French Department of Legal Translation Center, CUPL, Researcher of Beijing Applied Law Research Center, Beijing, China

Dong-lei GUO

Criminal law doctor of CUPL, Beijing, China

\begin{abstract}
With increasing prevalence of western learning, in the Chinese academia, there are many misunderstandings on the Chinese traditional legal philosophy or Chinese legal system. In the paper, with regard to the most fundamental issues in the Chinese legal system, new explanations are given based on the latest research results concerning the science of law (especially the legal history) to correct such misunderstandings. They are of significance for studying, succeeding and carrying forward the essences of the Chinese traditional legal philosophy.
\end{abstract}

KEY WORDS: Chinese legal system; right; obligation; rule of man; "all-in-one of laws"; civil law; criminal law

With increasing prevalence of western learning since the late Qing Dynasty, many legal scholars have studied foreign legal systems, cultures and philosophies, and introduced western legal systems with the hope of their growth in China. Such modesty is admirable. The Chinese legal system and legal culture can be enriched by developing what is useful and discarding what is not from western laws. However, if western laws are blindly worshiped and the superiority of the Chinese legal culture is ignored, or even the legitimacy of "rule of law" in the Chinese history is ignored, what is useful won't be learnt, and what is not useful may be developed by mistake due to loss of discernment. The current academia runs over with excessive critique and hypercorrection of the Chinese legal culture. Commonly, some scholars partly affirm the Chinese legal system with the aim of justifying western laws; some scholars preach about the western "rule of law" without regard to the excellent academic "gene" of the Chinese legal system. Such scholarship is biased in both methodology and direction.

In fact, there's no impassable gulf between the Chinese legal system and the current western "rule of law", which were generated based on the Chinese traditional culture and the Roman culture, respectively. Communication, as well as complementation and fusion, is feasible between

This paper is the research achievement of the "funded project of program supporting the training of excellent young and middle-aged teachers of CUPL". them. In the book Coincidence and Difference between Legal Cultures of China and West, the Prof. Fan Zhongxin ingeniously described the difference between the Chinese legal culture and the western legal culture like "the western legal culture is a kind of rigorous science, while the Chinese legal culture is a kind of art."[1] Given this, we should carefully criticize many scholars' misunderstandings on a few fundamental issues in the Chinese legal system.

Chinese have been lost in cultural inferiority complex since the country was opened forcibly by western countries in the modern times. Such inferiority is primarily attributed to inactivation of traditional legal and cultural consciousness in the Chinese legal system. The existing legal system of China has disadvantages like inadequate localization and practicality due to such cultural consciousness. Consequently, China is still on the stage of learning from other countries, and hasn't formed a true legal culture system with Chinese characteristics. With regard to the Chinese legal tradition, not a few scholars hold that the Chinese traditional legal philosophy is obligation-based, or the Chinese traditional legal philosophy is "rule of man", or the Chinese traditional legal system is oriented to serving concentration of power, or the Chinese legal system has the disadvantage "all-in-one of laws, no discrimination between civil law and criminal law". These views relate to core issues in cognition of the Chinese legal system, and are arguable as considered by us. For example, someone holds that "different from the right-based legal system adapted to the 
commodity economy, the Chinese traditional legal culture is obligation-based and adapted to the natural economy, and involves distribution of rights and obligations as an important measure for consolidating the autocratic monarchy and strengthening the patriarchal clan system" [2]; someone holds that "the legal system in the feudal China is basically oriented to maintaining monarchs' interests, thus is obligation-based. Such system is formed on specific bases of ethics, economy, philosophy and politics, and tightly associated with the patriarchal hierarchy in the feudal China."[3] In our opinion, the scholars with such typical view should not build their knowledge structures fully based on western learning. If carefully reading authentic legal classics of the ancient China and studying the value, spirit and ideal of the Chinese legal system, they won't draw such arbitrary conclusion. We will demonstrate unreasonableness in the 3 conclusions above from a new angle.

\section{THE CHINESE LEGAL SYSTEM IS OBLIGATION-BASED?}

\subsection{Right - interest; obligation - negative interest}

The legal philosophy of the Chinese legal system is not obligation-based, neither aimed at fettering nor serving concentration of power or dictatorship. However, some academic conclusions are blindly followed by scholars prejudiced by preconceived ideas and short of the ability to think independently. Since the two footstones of the Chinese legal system are punishment and etiquette, people tend to misunderstand that the Chinese traditional laws focus on deterrence with punishments but ignore rights, and the concept "right and obligation" with the contemporary western connotation and denotation has never occurred, and is impossible to occur on the land nourished by the Chinese culture. "Right" and "obligation" are not only legal concepts, but also political, ethical and philosophical concepts, substantially oriented to "interest" and "negative interest". Although not equal to interest and negative interest, essentially, right and obligation are legalized interest and negative interest, respectively. Absence of concept of right or obligation doesn't mean there's no interest or negative interest in Chinese traditional laws. In criminal laws of the ancient China, negative interests are listed in a unique way, namely what can't be done and what must be done are described in detail, and what can be done and how to do are regulated by etiquette. How can this be "obligation-based"?

\subsection{Code and etiquette}

In discussing characteristics of legislation in the Chinese legal system, besides focus on statute laws, the Chinese unique etiquette should be studied in depth. Upon thousands of years of development and perfection, it has been a unique and complete "soft law" system. As considered by the famous civil jurist Mr. Mei Zhongxie, numerous spirits of the continental law system are contained in the Chinese ritual philosophy. Therefore, when learning that the mode of enumerating prohibitory provisions is extensively adopted in Chinese ancient codes, one shouldn't assertively associate them to backwardness or cruelness. All behaviors not prohibited are discretional, and regulated by perfect etiquette. Etiquette plays the role of buffer in judicature and criminal law. Although different from each other essentially, etiquette has the same effect with private laws in the continental law system. Etiquette was formed on the condition of focus on rule of virtue and moralization in the Chinese traditional legal culture. After learning the moral system of the country, a lawmaker first prepares an etiquette system for following, then develops criminal laws to keep virtual running of the system. In Chinese traditional laws, obligations are clearly listed to correct misdeeds threatening normal running of the society by means of punishment. Declaring prohibitions to the public in a legal system (e.g. by developing a punishment code against the behaviors that should be denied by the state like lack of filial piety, incest and fornication) is aimed at maintaining purity and effectiveness of the social moral system. In a sense, in the ancient China, a scope of obligation was defined for people, and all the things out of such scope were people's rights. That is, any behavior not prohibited by the state was discretional for people. To some extent, this is freer than the Roman legal system comprised of listed rights and obligations.

\subsection{Civil customary law}

The core of the view "the Chinese legal system is obligation-based" is "China has no tradition of private law; in the Chinese legal system, all behaviors are regulated by public laws". We think this is wrong. As studied by the civil jurist of CUPL, Prof. Li Xiandong, the wrong conclusion is drawn for the reason as follows: In the modern times, the fact that most Chinese ancient codes are criminal codes has been learnt by all Chinese researchers, thus from the angle of form of basic code, in the traditional legal theory, "all-in-one of laws, no discrimination between civil law and criminal law, punishment first" is viewed as an important characteristic of Chinese ancient codes. The mainstream view is that there's no private law or civil law in the ancient China. As a result, students are imbued with the customary statement "there's no civil law in the ancient China. 
In our opinion, there's a lingering ossification in the Chinese academia. In other words, academic innovations are troubled by "parrot". In fact, socalled "civil law" refers to the private law system constituted in the Renaissance based on the civil law of the ancient Rome, which was generated based on specific natural, social, cultural and economic backgrounds of the ancient Rome. When it comes to these backgrounds, the ancient China is entirely different from the ancient Rome. However, despite of such difference, trades are necessary in both the ancient China and the ancient Rome. Different trade rules are generated under different cultures, thus gestate different private law systems. Early in 1985, the famous expert of legal history Mr. Zhang Jinfan pointed out in his paper that "land deeds" written on bricks from unearthed tombs of the Han Dynasty specified boundaries, witnesses, inviolability, etc. Among them, the famous brick "Yang Shao's Land Deed" shows the words "private contract shall be as valid as law"; the brick "Pan Yanshou's Land Deed" shows the words "private contract shall be viewed as law".[4] From the above, in China, the concept "contract equals law" has occurred not later than the Han Dynasty. That is, the concept that a private contract is as valid as law for the parties has been age-old in the folk of the ancient China, and civil customary laws corresponding to law with focus on autonomy of will have been persistent.[5] Obviously, the view "China has no tradition of private law, the Chinese legal system is obligationbased" is ungrounded.

\section{THE CHINESE LEGAL SYSTEM CENTERS AROUND "RULE OF MAN"?}

In fact, the argument between "rule of man" and "rule of law" is not a true academic issue, but falls within the scope of idea, since there's no universally accepted concept of "rule of man" in theory circles. If "rule of man" is defined as "wanton rule of a man" or rule of a man pursuant to his preference or desire, anyone won't admit that the Chinese judicial system, which has been for thousands of years, is "rule of man". It is obviously improper to take such a concept without specific connotation or detonation as a basic term or label the Chinese legal culture with it, just as said by the famous legalist, Prof. Wu Shuchen: "the 'rule of man' proposed by Confucians before the Qin Dynasty and some ideologists in the feudal China is partly comparable to the 'philosopher politics' proposed by Plato. However, neither of the two proposals is associated with 'replace laws with man', 'replace laws with dictation' or 'will of the leader'. In fact, what the traditional 'rule of man' emphasizes is, compliant 'sages' or 'gentlemen' able to execute systems must be selected in appointment. An emperor is required to be decent and preclude 'bring disaster to the nation by a mere word', and officials are required to be law-abiding. Denouncing the traditional 'rule of man' without analysis will obstruct promotion of excellent cultural traditions."[6]

The core spirit of Chinese ancient laws is rule of virtue and etiquette, rather than rule of man. Confucians advocate that a country should be governed by virtuous sages, by means of moralization. They emphasize rule of virtue depending on personal effects. Although Chinese laws advocate "governance by man", one shouldn't conclude that the Chinese traditional legal philosophy centers around "rule of man". For example, all people say the USA is a country under rule of law, nevertheless, judges there have extensive powers and discretions. When a judge considers that a legal precedent is unmatched with the present situation, he can deny and enter a judgment contrary to the precedent, thus generate a new precedent. Furthermore, when a judge considers that a law is contrary to the spirit of the constitution, he can directly declare the law violates the constitution and is invalidated. This is so-called "law creating by judge". Mencius (a great ideologist of the Warring States Period) said: "ruling shall not only depend on goodness, a good law can not enforce itself."[7] In such "rule of man", a judge's discretion is brought into full play on the condition of laws. This is of no unreasonableness. In the context of western juridical philosophy, the goddess who upholds justice and maintains orderliness is Themis. The goddess of law and justice is generally depicted as a blindfolded goddess who wears a surplice and a crown with a balance in her left hand and a sword in her right hand. The core of such depiction is to exhort judges to be based on laws and invulnerable to popular wills. In this sense, trials by judges of the USA should not be simply viewed as "rule of man" or "rule of law". Similarly, it is proper to hold that China had been under rule of virtue, rather than rule of man, from of old. Laws are indispensable. However, their enforcement depends on rulers' moral.[8] An emperor is required to make himself an example, unveil policies of benevolence, respect sages and capable brains, and appoint competent officials to promote rule of rite thus keep enforcement of the policies he unveils all his life.[9] Given this, what the Chinese ancient legal philosophy centers around is rule of virtue and etiquette.

\section{3 "ALL-IN-ONE OF LAWS, NO DISCRIMINATION BETWEEN CIVIL LAW AND CRIMINAL LAW"?}

By deeply comparing and studying law forms as well as contents and structures of many 
representative laws of the ancient China, Mr. Yang Yifan (Institute of Law of Chinese Academy of Social Sciences) holds that "There were multiple law forms in the ancient China, and different dynasties, from the period before the Qin Dynasty to the Ming and Qing Dynasty, had different law forms. The Qin Dynasty adopted the law forms 'Lü', 'Ming', 'Ling', 'Zhi', 'Zhao', 'Cheng', 'Shi', 'Ke', 'legal Q \& A (Fa Lü Da Wen)' and 'legal precedent (Ting Xing Shi)'; the Han Dynasty adopted 'Lü', 'Ling', 'Ke', 'Pin' and 'Bi'; the Jin Dynasty adopted 'Lü' and 'Ling', 'legal precedent (Gu Shi)'; the Sui and Tang Dynasty adopted 'Lü', 'Ling', 'Ge' and 'Shi'; in addition to 'Lü', 'Ling', 'Ge' and 'Shi', the Song Dynasty emphasized 'imperial order (Bian Chi)', and adopted 'Duan Li' and 'Zhi Hui'; the Yuan Dynasty laid stress on 'Tiao Ge' and 'Duan Li'; in addition to 'Lü', the Ming and Qing Dynasty emphasized 'Bian Li', and unveiled 'Yu Zhi', 'Gao', 'Bang Wen', 'local regulation (Di Fang Fa Gui)' and 'folk convention (Xiang Gui Min Yue)'.'[10] A "Lü" is a criminal code, namely a criminal law, rather than an assembly of laws. Legal provisions on civil affairs, administration, economy and military affairs were mostly contained in the other forms mentioned above. Also, Mr. Chen Guyuan pointed out that 'Besides 'Lü', there's 'Ling' (for regulating national systems), 'Ge' (for handling political affairs), 'Shi' (for setting up institutions), 'Ke' (for stating legal precedents) and 'Dian' (for organization). They were not always supplements to or substitutes for 'Lü' in each dynasty." [11] That is, "Lü" and the other law forms were cooperative and complementary. Therefore, the theory of "all-in-one of laws" is ungrounded.

Here we take the Tang Dynasty, a period when the Chinese ancient legal system got mature, for example. The law forms adopted in the Tang Dynasty were "Lü", "Ling", "Ge" and "Shi". In detail, "Lü" is a basic law for condemnation and measurement of penalty; "Ling" specifies classes, statuses, rules and regulations; "Shi" specifies detailed handling rules for state organs and formats of official documents. "Ge" is derived from "Zhi" and "She" provisionally unveiled by emperor for specific persons or affairs. To avoid inconsistency during enforcement, provinces and ministries were periodically ordered to assemble complicated "Zhi" and "She" to stable systems with generality. Such assembly was called "Yong Ge". In short, "Ling" and "Shi" directly specify rules and regulations; "Lü" is intended for punishing criminals; "Ge" refers to corrective and supplementary measures for "Lü", "Ling" and "Shi". The cooperative four forms constitute the national legal system. Seen from this, "Lü" is no more than one kind of law. It is improper to deem "Lü" as "all-in-one law", not to mention "all-in-one of laws" as a characteristic of the Chinese legal system.
Furthermore, it is necessary to correct the view "no discrimination between civil law and criminal law". The Prof. Li Xiandong pointed out: "It is undoubted that flourishing international and domestic trades once occurred in the ancient China. Although laws were expressed in different forms due to cultural difference, since they all targeted commodity exchange, why can't the rule or similar rules derived be viewed as civil law?'[12] In the ancient China, with development of the private ownership, civil regulations on land, household, marriage and debt were unveiled, and got more and more complicated. They were specified in a code or independently made into a decree to regulate specific property relationships, personal relationships as well as private right-obligation relationships. "The affairs regulated by customary laws in the ancient China, such as marriage, property division, inheritance, transaction, leasing, mortgage and loan, also play an important part in modern civil laws. They were ignored or only outlined in ancient codes. It is folk customary laws that made up and set the stage for folk life, especially economic life therein.'[13] Besides, in the ancient China from the Qin Dynasty, the rule that a judge must try a case by citing "Lü", which was applicable to criminal proceedings, was inapplicable to civil cases. "To settle numerous civil disputes, a judge was allowed to apply sources other than legal provisions, such as rite, customs, family discipline and clan regulation.’'[14]

Mr. Chen Guyuan, a famous expert of legal history in the 20th century, once vigorously refuted "no discrimination between civil law and criminal law". He first discriminated the level of civil trial and the level of criminal trial from the angle of procedural law, then argued from the angle of substantial law that involvement of civil relationships in criminal codes should not be an evidence proving substantial laws were combined into criminal codes. Besides, he pointed out that part of the Chinese "rite" was equivalent to civil substantial law. Based on a lot of historical data he mastered, Mr. Zhang Jinfan offered research results concerning civil laws of the ancient China in the 1million-character book General History of Chinese Civil Laws, in a systemic and detailed way. In the History of Chinese Civil Laws, Ye Xiaoxin systemically discussed civil laws and civil procedures of the ancient China.

To sum up, in the Chinese legal system, different laws are independent of each other, and there's discrimination between civil law and criminal law. Criminal code played the major role in dynasties, but numerous laws on administration and civil affairs were not contained therein. 


\section{SUMMARY}

Prof. Zhang Zhongqiu (CUPL) holds that by analyzing the Tang Code and the Institutes of Justinian, the moral principle of the Chinese legal system and the freedom principle of the Roman law can be revealed, and it can be concluded that from the angle of natural philosophy, the two principles are based on the organic view of nature and the inorganic view of nature, respectively. The moral principle targets all people, emulates nature and pursues harmony. It brings about the responsibilityright structure, the moral spirit and the value goal of the Chinese legal system (co-existence and common prosperity of all people, human and nature). The freedom principle targets individuals, pursues justice and is based on rationality. It brings about the rightobligation structure, the freedom spirit and the value goal of Roman law (independence and progress of human). In value, the two principles are eternal and complementary, since a man is an individual, but human is a group, and both moral and freedom are necessary for human. Given this, with a view to force of the tradition, value of the moral principle and the development trend of China, especially that the Chinese organic view of natural has been supported by new science and philosophy, the moral principle will be significantly instructive in learning and solving divorce of western systems from the Chinese society and determining which laws should be applied in settling human disputes and global ecological crises.[15]

\section{REFERENCES}

[1] Fan Zhongxin, Coincidence and Difference between Legal Cultures of China and West, China University of Political Science and Law Press, 2001.

[2] Gong Pixiang, Chinese Traditional Legal Culture and Obligation Standard, Study \& Exploration, Issue 6, 1991.

[3] Kang Yujuan, Cause of the Chinese Traditional Legal View "Obligation-based", Journal of Tianshui College of Administration, Issue 2, 2004.

[4] Verification of "Private Contract Shall Be as Valid as Law", Tribune of Political Science and Law, May 2007

[5] Verification of "Private Contract Shall Be as Valid as Law", Tribune of Political Science and Law, May 2007

[6] Wu Shuchen, Ma Xiaohong, Argument between "Rule of Man" and "Rule of Law" in Ancient China, Knowledge of Literature and History, Issue 1, 1991.

[7] Mencius, The Mencius-Lilou, 1

[8] Confucius, The Analects of Confucius-Zilu

[9] Confucius, Book of Rites-Moderation

[10] Yang Yifan, A Significant Misunderstanding in Study on Chinese Law System—Doubt about "All-in-one of Laws, No Discrimination between Civil Law and Criminal Law”, Social Sciences in China, Issue 2, 2002.

[11] Chen Guyuan, Histories of Rule of Law and Rule of Rite, Fudan Journal, Issue 1, 1944.

[12] Li Xiandong, Transformation from the Great Qing Legal Code to the Civil Code of the Republic of China and Innate Open System of Civil Law in Ancient China, Doctoral Dissertation of CUPL, August 2003.

[13] Liang Zhiping, Customary Laws of Qing Dynasty: Society and Nation, China University of Political Science and Law Press, p. 37, Edition 1, June 1996.

[14] Zhang Jinfan, Introduction to Civil Actions in Ancient China, Law and Social Development, March 1996.

[15] Zhang Zhongqiu, Comparison between Chinese Law System and Roman Law System in Principle and Philosophy_Illustrated by the Tang Code and the Institutes of Justinian, Tribune of Political Science and Law, Issue 3, 2010. 